\title{
Changes in mineralogical and leaching properties of converter steel slag resulting from accelerated carbonation at low $\mathrm{CO}^{2}$ pressure
}

\author{
André van Zomeren ${ }^{a}$ \\ Sieger R. van der Laan ${ }^{b}$ \\ Hans B.A. Kobesen ${ }^{c}$ \\ Wouter J.J. Huijgen ${ }^{\text {a }}$ \\ Rob N.J. Comans ${ }^{\text {a,d }}$ \\ ${ }^{a}$ Energy Research Centre of the Netherlands (ECN), The Netherlands \\ ${ }^{b}$ Tata Steel RD\&T, Ceramics Research Centre, The Netherlands \\ ${ }^{c}$ Tata Steel Strip Products, OSF2, The Netherlands \\ ${ }^{d}$ Wageningen University, Department of Soil Quality, The Netherlands
}

Published in Waste Management 31 (2011) 2236-2244 


\title{
Changes in mineralogical and leaching properties of converter steel slag resulting from accelerated carbonation at low $\mathrm{CO}_{2}$ pressure
}

\author{
André van Zomeren ${ }^{a}$, Sieger R. van der Laan ${ }^{b}$, Hans B.A. Kobesen ${ }^{c}$, Wouter J.J. Huijgen ${ }^{a}$, \\ Rob N.J. Comans ${ }^{\mathrm{a}, \mathrm{d}, *}$ \\ a Energy Research Centre of the Netherlands (ECN), P.O. Box 1, 1755 ZG Petten, The Netherlands \\ ${ }^{\mathrm{b}}$ Tata Steel RDET, Ceramics Research Centre, P.O. Box 10000, 1970 CA IJmuiden, The Netherlands \\ ${ }^{\mathrm{c}}$ Tata Steel Strip Products, OSF2, P.O. Box 10000, 1970 CA IJmuiden, The Netherlands \\ ${ }^{\mathrm{d}}$ Wageningen University, Department of Soil Quality, P.O. Box 47, 6700 AA Wageningen, The Netherlands
}

\section{A R T I C L E I N F O}

\section{Article history:}

Received 1 December 2010

Accepted 31 May 2011

Available online 8 July 2011

\section{Keywords:}

Steel slag

Carbonation

Leaching

Vanadium

Mineralogy

\begin{abstract}
A B S T R A C T
Steel slag can be applied as substitute for natural aggregates in construction applications. The material imposes a high pH (typically 12.5) and low redox potential (Eh), which may lead to environmental problems in specific application scenarios. The aim of this study is to investigate the potential of accelerated steel slag carbonation, at relatively low $\mathrm{pCO}_{2}$ pressure $(0.2$ bar), to improve the environmental $\mathrm{pH}$ and the leaching properties of steel slag, with specific focus on the leaching of vanadium. Carbonation experiments are performed in laboratory columns with steel slag under water-saturated and -unsaturated conditions and temperatures between 5 and $90{ }^{\circ} \mathrm{C}$. Two types of steel slag are tested; free lime containing (K3) slag and K1 slag with a very low free lime content. The fresh and carbonated slag samples are investigated using a combination of leaching experiments, geochemical modelling of leaching mechanisms and microscopic/mineralogical analysis, in order to identify the major processes that control the slag $\mathrm{pH}$ and resulting $\mathrm{V}$ leaching. The major changes in the amount of sequestered $\mathrm{CO}_{2}$ and the resulting $\mathrm{pH}$ reduction occurred within $24 \mathrm{~h}$, the free lime containing slag (K3-slag) being more prone to carbonation than the slag with lower free lime content (K1-slag). While carbonation at these conditions was found to occur predominantly at the surface of the slag grains, the formation of cracks was observed in carbonated K3 slag, suggesting that free lime in the interior of slag grains had also reacted. The $\mathrm{pH}$ of the $\mathrm{K} 3 \mathrm{slag}$ (originally $\mathrm{pH} \pm 12.5$ ) was reduced by about 1.5 units, while the $\mathrm{K} 1$ slag showed a smaller decrease in $\mathrm{pH}$ from about 11.7 to 11.1 . However, the $\mathrm{pH}$ reduction after carbonation of the K3 slag was observed to lead to an increased V-leaching. Vanadium leaching from the K1 slag resulted in levels above the limit values of the Dutch Soil Quality Decree, for both the untreated and carbonated slag. V-leaching from the carbonated $\mathrm{K} 3$ slag remained below these limit values at the relatively high $\mathrm{pH}$ that remained after carbonation. The V-bearing di-Ca silicate (C2S) phase has been identified as the major source of the V-leaching. It is shown that the dissolution of this mineral is limited in fresh steel slag, but strongly enhanced by carbonation, which causes the observed enhanced release of $\mathrm{V}$ from the K3 slag. The obtained insights in the mineral transformation reactions and their effect on $\mathrm{pH}$ and $\mathrm{V}$-leaching provide guidance for further improvement of an accelerated carbonation technology.
\end{abstract}

(c) 2011 Elsevier Ltd. All rights reserved.

\section{Introduction}

The annual steel production reaches about 1.3 billion tonnes world-wide (Worldsteel, 2010). Since modern integrated LD/converter steelplants produce about $90-100 \mathrm{~kg}$ of steel slag per tonne of steel, vast amounts of steel slag are being co-produced (Worldsteel, 2010). The steel (LD/converter) slag is a stony material that,

* Corresponding author at: Energy Research Centre of the Netherlands (ECN), P.O. Box 1, 1755 ZG Petten, The Netherlands. Tel.: +31 22456 4218; fax: +31 22456 8163.

E-mail address: comans@ecn.nl (R.N.J. Comans). after cooling, resembles basalt. The cooling method (rapid/slow, with or without water), together with the mineralogy, determines the properties of the obtained stony aggregates, such as surface quality, (major- and minor-element) leachability and the volume expansion behaviour. It is well established that free lime in converter slag is a major determinant regarding the material properties (Shi, 2004). The aggregates can be used in many applications as substitute for natural aggregate materials, but impose a high $\mathrm{pH}$ (typically between 11.5 and 12.5) and low redox potential (Eh). While the materials generally comply with current regulatory limit values, e.g. in the Netherlands, the high $\mathrm{pH}$ and/or reducing properties can lead to environmental problems in specific applica- 
tion scenarios with limited water flow and/or limited access of $\mathrm{CO}_{2}$ and $\mathrm{O}_{2}$ to the material, which hampers the carbonation and oxidation of the slag that would normally occur in contact with the atmosphere. Currently, there are no specific environmental criteria in the Netherlands for (re)use of (secondary) construction materials with regard to $\mathrm{pH}$ and Eh or the associated buffering capacities. Therefore, a decision scheme is being developed based on rules for the acceptance of construction materials in these specific applications.

A possible technology to reduce the $\mathrm{pH}$ of alkaline slags is carbonation. Carbonation of steel slag has been studied using a wide range of process conditions from ambient to elevated pressure and temperature (Baciocchi et al., 2009; Bonenfant et al., 2008; Huijgen et al., 2005; Lekakh et al., 2008). The aim of this study is to apply (enhanced) carbonation for the purpose of improving the environmental $\mathrm{pH}$ and leaching properties of converter steel slag. Two types/qualities of slags are considered that cover the full range of typical compositions of converter slag. Our optimisation of the process conditions is not aimed at maximising the $\mathrm{CO}_{2}$ sequestration, but rather at reaching a substantial reduction of the alkaline slag $\mathrm{pH}$ while complying with regulatory limit values for contaminant leaching. Special attention is paid to the leaching of vanadium that is of specific concern with respect to the environmental quality of specific types of steel slags (Presslinger and Klepp, 2002). Accelerated carbonation of steel slag is performed at relatively low $p \mathrm{CO}_{2}$ pressure ( 0.2 bar) at about the same concentrations as present in the process gasses of the steel plant. Experiments were performed under water-saturated and unsaturated conditions. The fresh and carbonated steel slag samples are studied for their mineralogical composition and controlling leaching processes, in order to evaluate the nature and sustainability of the observed changes in slag properties.

\section{Materials and methods}

\subsection{Steel slag feedstock}

Two qualities of rapid air-cooled slag from the basic oxygen steelmaking process, differing in free lime content, were used in this study to cover the full range of typical converter/LD slag compositions. Type K1 slag contains $0-3 \mathrm{wt}$ \% free lime forming by minor free lime $(\mathrm{CaO})$ crystallization at the solidus. Type $\mathrm{K} 3 \mathrm{con}-$ tains more than $6 \mathrm{wt} . \%$ free lime and the lime crystallizes at temperatures above the solidus (Geiseler, 1995). These type indications $\mathrm{K} 1, \mathrm{~K} 3$ are slag definitions used at the production site of TATA Steel IJmuiden, The Netherlands. All slags represent single converter heats, and were air-cooled and subsequently broken and sieved to obtain a representative $2-3.3 \mathrm{~mm}$ fraction of starting material for the experiments. Samples were stored dry in a closed container under a $\mathrm{N}_{2}$ atmosphere. The native $\mathrm{pH}$ of the $\mathrm{K} 1$ and $\mathrm{K} 3$ steel slag batches was $11.7-11.8$ and $12.4-12.7$, respectively.

\subsection{Mineralogical characterisation}

Mineralogy of the slag samples was determined using powder X-ray diffraction (XRD), reflected light microscopy and scanning electron microscopy (SEM) with microanalysis (EDS). For XRD, a few grams of the starting material was ground in a tungsten-carbide ball mill to below $15 \mu \mathrm{m}$, no internal standard was used. $\mathrm{XRD}$-patterns were acquired from $10^{\circ}$ to $130^{\circ}$ 2-theta with a Bruker D4 diffractometer using $\mathrm{Co}-\mathrm{K} \alpha$ radiation and a Vantec detector. The software package Topas (Bruker) was used to perform Rietveld quantification. To fit the pattern we used two types of wuestite (Fe-wuestite and Mg-wuestite) two polymorphs of di-Ca silicate (larnite and $\alpha-\mathrm{C} 2 \mathrm{~S}$ ), srebrodolskite, portlandite, calcite, aragonite and lime. Lime was detected on the basis of two free-lying peaks at near $44^{\circ}$ and $64^{\circ} 2$-theta, related to its cubic crystal structure, which allows reliable quantification down to $0.5 \mathrm{wt} . \%$.

In addition to the XRD analyses to determine the structure, SEM-EDS was used to quantify the amounts of elements incorporated in the different minerals. For reflected light microscopy and SEM-EDS, polished grain-mounts were prepared of slag before and after carbonation. SEM-EDS was carried out with a JEOL 7001 operating at $15 \mathrm{kV}$ and $10 \mathrm{nA}$, equipped with dual Silicon Drift Detectors with a Noran System 7 (NS7) platform. Spectra (EDS) were interpreted using NS7 software.

\subsection{Carbonation experiments}

Carbonation experiments at atmospheric pressure were performed in a glass column (Pharmacia XK-50/30, inner diameter $5 \mathrm{~cm}, 20 \mathrm{~cm}$ height) with a thermostatic jacket. About $900 \mathrm{~g}$ steel slag was wetted (see below) and placed in the column. A CO $2 / \mathrm{Ar}$ gas mixture $\left(20 \% \mathrm{CO}_{2}, 80 \% \mathrm{Ar}\right)$ was water-saturated at elevated temperature, to ensure the presence of water in the experiments, and was introduced in an up-flow direction at a flow rate of about $400 \mathrm{~mL} / \mathrm{min}$. Experiments were performed at 5, 20, 50, 70 and $90{ }^{\circ} \mathrm{C}$ under water-saturated and unsaturated exposure for mostly $24 \mathrm{~h}$. The effect of time (8-200 h) on carbonation was studied under water-saturated and unsaturated exposure at $90^{\circ} \mathrm{C}$. The experiments with unsaturated water conditions were performed by wetting the steel slag to an $L / S$ ratio of about $0.01-0.1 \mathrm{~L} / \mathrm{kg}$. Based on preliminary experiments, the moisture content was increased to an $\mathrm{L} / \mathrm{S}$ ratio of about $0.4 \mathrm{~L} / \mathrm{kg}$ for experiments with reaction times greater than $24 \mathrm{~h}$ to avoid drying of the steel slag during the test. Water was added, and the amounts registered (usually between 5 and $10 \mathrm{~mL}$ per addition), in several steps during the course of the experiment to prevent drying of the material while keeping the conditions unsaturated (moisture content ranged from $2 \%$ to $10 \%$ during the experiments). In the water-saturated experiments the total free volume between the slag grains was occupied by water and surplus water was added during the experiment to compensate for evaporation due to the gas flow and/or the elevated temperatures of the carbonation. As a result, the corresponding $L / S$ ratio in the columns varied between 0.4 and $2 \mathrm{~L} / \mathrm{kg}$ during the carbonation experiments.

The carbonation efficiency was quantified by thermogravimetrical analysis (Mettler-Toledo TGA/SDTA 851e) coupled to a Pfeiffer (thermostar) Quadrupole mass spectrometer (TGA-MS). About 20$50 \mathrm{mg}$ of finely ground $(<106 \mu \mathrm{m})$ steel slag (Huijgen et al., 2005) was weighed in a ceramic cup and heated from 25 to $1000^{\circ} \mathrm{C}$ under a nitrogen atmosphere at a heating rate of $40^{\circ} \mathrm{C} / \mathrm{min}$. The weight loss was recorded by the TGA microbalance and the amount of carbonate was quantified by the weight loss observed between 500 and $1000^{\circ} \mathrm{C}$, which was verified by the MS detection of only $\mathrm{CO}_{2}$ in that temperature range. Further details on the TGA-MS method are provided in Huijgen et al. (2005).

\subsection{Leaching tests and characterisation}

\subsubsection{Batch $\mathrm{pH}$-static leaching experiments}

Both the K1 and K3 type steel slag samples were leached at a liquid to solid $(L / S)$ ratio of $10 \mathrm{~L} / \mathrm{kg}$ for $48 \mathrm{~h}$ in acid-cleaned $300 \mathrm{~mL}$ PTFE vessels at eight different $\mathrm{pH}$ values. The $\mathrm{pH}$ values of the suspension were adjusted (between 2 and 12) using a computerized $\mathrm{pH}$-stat system. The $\mathrm{pH}$ of one of the suspensions was not adjusted in order to assess the leaching at the 'native' $\mathrm{pH}$ value of the suspension. Solutions of $1 \mathrm{M} \mathrm{HNO}_{3}$ and $\mathrm{NaOH}$ (analytical grade) were used to adjust the $\mathrm{pH}$ of the suspensions which were in contact with the atmosphere, continuously stirred and kept at a constant temperature of $20^{\circ} \mathrm{C}$. After the equilibration period, the 
suspensions were filtered through pre-washed $0.45 \mu \mathrm{m}$ membrane filters. The filtrates were preserved with concentrated $\mathrm{HNO}_{3}$ (suprapure) and analysed by ICP-AES to obtain solution concentrations of 29 major and minor elements.

\subsubsection{Column leaching test}

Column leaching (percolation) tests were performed according to CEN/TS 14405 (2005) on the K1 and K3 type steel slag. The steel slag was added to a borosilicate glass column (inner diameter $5 \mathrm{~cm}$ ) in layers of a few $\mathrm{cm}$ and packed by shaking and pushing gently with a rod to a filling height of $\pm 20 \mathrm{~cm}$. Nanopure demineralised water was used as the leachant. The packed columns were water-saturated and pre-equilibrated for $72 \mathrm{~h}$, after which the influent was pumped in up-flow direction. Computer-controlled flow controllers assured a constant flow velocity during the experiments. Fractions were collected automatically at cumulative $L / S$ values of $0.1,0.2,0.5,1,2,5$ and $10(\mathrm{~L} / \mathrm{kg})$. Effluent fractions were collected in acid-cleaned PE bottles. Shortly after collection of each effluent fraction, $\mathrm{pH}$, redox potential (Eh) and conductivity were determined, and sub-samples for chemical analysis were taken and filtered through $0.45 \mu \mathrm{m}$ membrane filters. The filtered leachates were preserved with concentrated $\mathrm{HNO}_{3}$ (suprapure) and analysed for 29 major and minor elements by ICP-AES.

\subsubsection{Geochemical modelling}

Geochemical modelling was performed on the $\mathrm{pH}_{\text {stat }}$ leachates from fresh and carbonated (K1 and K3) steel slag to identify the leaching processes and inferred changes in mineral composition. The database/expert system LeachXS (van der Sloot et al., 2003) in combination with the geochemical modelling framework ORCHESTRA (Meeussen, 2003) was used for this purpose. Potential solubility control was evaluated by calculation of mineral saturation indices (SI) of the minerals portlandite, CSH and calcite. The $\mathrm{SI}$ is defined here as $\log \left(\frac{\mathrm{IAP}}{K_{\mathrm{sp}}}\right)$ with IAP = ion activity product and $K_{\mathrm{sp}}=$ solubility product. The thermodynamic database used consisted of the MINTEQA2 database version 3.11 (Allison et al., 1991), extended with minor modifications as described by Dijkstra et al. (2002) and with solubility constants for Ca-silicates (i.e. CSHphases) (Gaucher et al., 2004). The total element concentration in solution corresponding with solubility control by a selected mineral was calculated as explained in detail by Meima and Comans (1997).

The dissolved carbonate concentrations were not analysed in the leachates. It was assumed that the eluates from fresh steel slag samples contained no dissolved carbonate. For the eluates from carbonated steel slag, total dissolved carbonate was assumed to be $10 \mathrm{mg} / \mathrm{L}$ over the whole $\mathrm{pH}$ range based on analyses of leachates from $\mathrm{pH}$-static leaching experiments with carbonated converter slag from the same steel plant (Huijgen and Comans, 2006).

\section{Results and discussion}

\subsection{Mineralogy of slag feedstock}

Since the primary mineralogy of the slag is being altered in the carbonation process it is important to characterise the starting materials in some detail. Mineralogy of the starting materials from Rietveld-XRD is presented in Table 1 and Fig. 1a and b. Mineral compositions determined with SEM-EDS are reported in Table 2 and form the basis for the formulas of Table 1 . In all fresh steel slags, $\mathrm{Ca}$ is mainly present in phases like free lime-portlandite $\left(\mathrm{CaO}-\mathrm{Ca}(\mathrm{OH})_{2}\right)$, Ca-silicate (C2S), and Ca-ferrite (C2F). Two K1slags are mentioned in Table 1. The $\mathrm{K} 1$-a was lowest in $\mathrm{CaO}-$ content resulting in high magnesio-wuestite (MW) and low Ca-ferrite $(\mathrm{C} 2 \mathrm{~F})$, with no free-lime and a small amount of magnetite. When we ran out of K1-a slag a replacement batch, K1-b, was prepared. This batch appeared to be more calcic, as expressed in the mineralogy with the presence of some free-lime and higher Ca-ferrite contents. The $\mathrm{K} 3$ slag sample contains about $8 \%$ free-lime when portlandite is counted as hydrated free-lime. It is similar in Ca-ferrite content to K1-b but lower in di-Ca silicate (C2S), as a consequence of its lower bulk silica content. Optical examination reveals that $\mathrm{K} 3$ contained considerable tri-Ca silicate (C3S), which exsolved to form $\mathrm{C} 2 \mathrm{~S}+$ free-lime. The latter exsolution minerals are detected with XRD, however the outline of C3S crystals are clearly recognized optically and their composition was analysed with SEM-EDS (Table 2).

The elemental composition of the major mineral phases among the three samples are similar, with the exception of $\mathrm{C} 2 \mathrm{~F}$ which has high Ti-contents in K1-a (Table 2). This is again an effect of Ca-deficiency, causing only small amounts of $\mathrm{C} 2 \mathrm{~F}$ to form, which preferentially accommodates the $\mathrm{Ti}$ of the slag. The element $\mathrm{V}$ is preferentially concentrated in the $\mathrm{C} 2 \mathrm{~S}$ and $\mathrm{C} 2 \mathrm{~F}$ phases.

\subsection{Carbonation of steel slag}

Carbonation processes and their effect on the leaching properties of steel slag are related to the mineralogy of the two slag types and alteration processes as a result of reaction with $\mathrm{CO}_{2}$. Fig. 1 shows the amount of sequestered $\mathrm{CO}_{2}$ and the development of the $\mathrm{pH}(L / S=10,48 \mathrm{~h})$ at a number of stages during the carbonation of $\mathrm{K} 1$ and $\mathrm{K} 3$ steel slag at a partial $\mathrm{CO}_{2}$ pressure of $0.2 \mathrm{bar}$, as a function of time (at $90^{\circ} \mathrm{C}$ ) and under both water-saturated and unsaturated conditions. Consistent with its content of free lime, the K3-slag is more prone to carbonation (about $15 \mathrm{~g} \mathrm{CO}_{2} / \mathrm{kg}$ ) than $\mathrm{K} 1$-slag (about $6 \mathrm{~g} \mathrm{CO}_{2} / \mathrm{kg}$ ). Assuming that the vast majority of sequestered $\mathrm{CO}_{2}$ has reacted with the (rapidly carbonating) free lime (Huijgen et al., 2005), the maximum $\mathrm{CO}_{2}$ uptake measured in the carbonation experiments (under conditions as outlined in Fig. 1) would correspond to $48 \%$ and $35 \%$ conversion of the free lime content of the $\mathrm{K} 1$ and $\mathrm{K} 3$ steel slags, respectively. Huijgen et al. (2005) have reported $\mathrm{CO}_{2}$ sequestration capacities of about $100-150 \mathrm{~g} \mathrm{CO}_{2} / \mathrm{kg}$ with ground $(<38 \mu \mathrm{m})$ steel slag under high temperature and pressure conditions. Given our aim to carbonate relatively large steel slag grains $(2-3 \mathrm{~mm})$, with a limited surface area, only low degrees of carbonation are reached. The surface area of the grains is known to be an important process parameter (Baciocchi et al., 2009; Huijgen et al., 2005).

The carbonation as a function of the reaction temperature was examined with the $\mathrm{K} 1 \mathrm{slag}$ and the results are presented in Fig. 2. After $24 \mathrm{~h}$ of carbonation with $\mathrm{K} 1 \mathrm{slag}$ under saturated conditions at higher temperatures $\left(50-90^{\circ} \mathrm{C}\right)$, the amount of sequestered $\mathrm{CO}_{2}$ was generally about a factor of 2 greater than that at room temperature. The experiments under unsaturated conditions did not show a significant effect of temperature (Fig. 2). In addition, the resulting $\mathrm{pH}$ showed no correlation with the reaction temperature in either the experiments under unsaturated or saturated conditions, as can be seen in Fig. 2 .

Fig. 1 shows that the carbonation rate is fastest at water-saturated conditions and the rate declines strongly after about $24 \mathrm{~h}$ under these conditions. In addition, the observed changes in the $\mathrm{pH}$ of the steel slag also take place within the first $24 \mathrm{~h}$ of reaction time. The $\mathrm{pH}$ of the K3 slag is lowered by about 1.5 units, suggesting that the material is substantially improved with respect to its alkalinity. This decrease is very similar to that observed earlier by Huijgen et al. (2005) for this (K3) type of steel slag at corresponding Caconversion. The K1 slag shows a smaller decrease in $\mathrm{pH}$ from about 11.7 to 11.1 within the first $24 \mathrm{~h}$ reaction time. The $\mathrm{pH}$ values after carbonation seem to stabilise around 11.0-11.3 for both slag types. It is concluded that the major changes in the material take place within the first $24 \mathrm{~h}$ of carbonation and that the resulting $\mathrm{pH}$ and 
Table 1

Modal mineralogy of steel slag feedstock as determined with Rietveld-XRD. Indicated substituting elements were taken from SEM-EDS analyses shown in Table 2.

\begin{tabular}{|c|c|c|c|c|c|c|c|}
\hline \multicolumn{2}{|l|}{ Slag batch nr. } & \multicolumn{2}{|l|}{ S6938 } & \multicolumn{2}{|l|}{$\mathrm{Z1268}$} & \multicolumn{2}{|c|}{ W8791 } \\
\hline Phase & Formula & $\mathrm{K} 1(\mathrm{a})$ & $1 \sigma$ & $\mathrm{K} 1$ (b) & $1 \sigma$ & K3 & $1 \sigma$ \\
\hline Magnesio wuestite (MW) & (Fe,Mg,Mn)O & 37.0 & 5.0 & 23.7 & 3.0 & 29.2 & 3.5 \\
\hline Free lime & $\mathrm{CaO}$ & 0.0 & & 1.6 & 0.8 & 5.4 & 1.0 \\
\hline Portlandite & $\mathrm{Ca}(\mathrm{OH})_{2}$ & & & & & 3.0 & 0.8 \\
\hline Di calcium ferrite (C2F) & $2 \mathrm{CaO} \cdot(\mathrm{Fe}, \mathrm{Ti}, \mathrm{Al}, \mathrm{V})_{2} \mathrm{O}_{3}$ & 13.2 & 2.0 & 25.6 & 3.0 & 25.7 & 3.0 \\
\hline Di calcium silicate (C2S) & $2 \mathrm{CaO} \cdot(\mathrm{Si}, \mathrm{P}, \mathrm{V}) \mathrm{O}_{4}$ & 49.1 & 5.0 & 49.2 & 5.0 & 36.6 & 5.0 \\
\hline Magnetite & $\mathrm{FeO} \cdot \mathrm{Fe}_{2} \mathrm{O}_{3}$ & 0.7 & & & & & \\
\hline
\end{tabular}
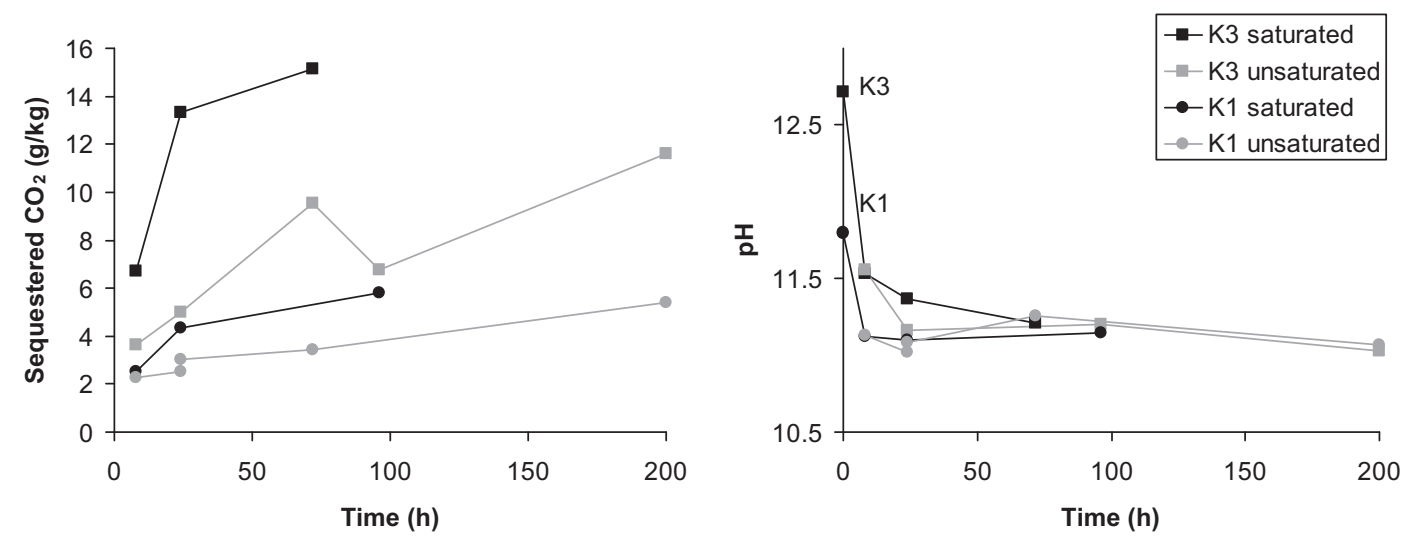

Fig. 1. Sequestered $\mathrm{CO}_{2}$ and resulting $\mathrm{pH}$ (at $L / S=10 \mathrm{~L} / \mathrm{kg}$, $48 \mathrm{~h}$ equilibration) in $\mathrm{K} 1$ and $\mathrm{K} 3$ steel slag particles (2-3.3 mm) as a function of reaction time during watersaturated and under-saturated conditions at 0.2 bar $p \mathrm{CO}_{2}$ and $T=90{ }^{\circ} \mathrm{C}$.

Table 2

Mineral composition of steel slag feedstock samples based on SEM-EDS analyses (\%wt.).

\begin{tabular}{lrrrlrrlrr}
\hline Phase & $\mathrm{MgO}$ & $\mathrm{Al}_{2} \mathrm{O} 3$ & $\mathrm{SiO}_{2}$ & $\mathrm{P}_{2} \mathrm{O}_{5}$ & $\mathrm{CaO}$ & $\mathrm{TiO}_{2}$ & $\mathrm{~V}_{2} \mathrm{O}_{5}$ & $\mathrm{MnO}$ & $\mathrm{FeO}$ \\
\hline $\mathrm{K} 1-\mathrm{a}, \mathrm{C} 2 \mathrm{~S}$ & 0.1 & 0.5 & 30.1 & 2.6 & 62.4 & 1.4 & 1.4 & 0.2 & 1.5 \\
$\mathrm{~K} 1-\mathrm{a}, \mathrm{MW}$ & 31.2 & 0.0 & 0.4 & 0.0 & 1.5 & 0.0 & 0.2 & 17.7 & 48.9 \\
$\mathrm{~K} 1-\mathrm{a}, \mathrm{C} 2 \mathrm{~F}$ & 0.8 & 6.6 & 2.3 & 0.1 & 44.3 & 10.2 & 2.0 & 2.0 & 31.9 \\
$\mathrm{~K} 1-b, \mathrm{C} 2 \mathrm{~S}$ & 0.2 & 0.9 & 28.0 & 3.0 & 61.0 & 1.1 & 1.7 & 0.4 & 2.5 \\
$\mathrm{~K} 1-b, \mathrm{MW}$ & 33.0 & 0.1 & 0.8 & 0.0 & 2.9 & 0.0 & 0.3 & 16.0 & 47.0 \\
$\mathrm{~K} 1-b, \mathrm{C} 2 \mathrm{~F}$ & 0.9 & 10.0 & 1.6 & 0.2 & 44.0 & 5.0 & 1.4 & 2.0 & 34.0 \\
$\mathrm{~K} 1-b, \mathrm{Lime}$ & 1.0 & 0.8 & 0.9 & 0.1 & 68.0 & 0.3 & 0.6 & 9.6 & 19.0 \\
$\mathrm{~K} 3, \mathrm{C} 2 \mathrm{~S}$ & 0.3 & 0.7 & 29.2 & 2.6 & 60.6 & 0.8 & 0.9 & 1.1 & 3.7 \\
$\mathrm{~K} 3, \mathrm{MW}$ & 30.2 & 0.0 & 0.3 & 0.0 & 2.8 & 0.0 & 0.1 & 12.5 & 54.1 \\
$\mathrm{~K} 3, \mathrm{C} 2 \mathrm{~F}$ & 0.7 & 4.0 & 1.1 & 0.1 & 43.5 & 4.6 & 2.0 & 1.5 & 42.5 \\
$\mathrm{~K} 3, \mathrm{C} 3 S^{\mathrm{a}}$ & 0.1 & 0.5 & 22.7 & 1.5 & 70.1 & 0.6 & 0.2 & 2.4 & 2.0 \\
$\mathrm{~K} 3$, lime & 0.8 & 0.1 & 0.3 & 0.2 & 79.7 & 0.2 & 0.0 & 7.6 & 11.0 \\
\hline
\end{tabular}

${ }^{a}$ Exsolved into C2S and lime.

amount of sequestered $\mathrm{CO}_{2}$ under these conditions should be feasible targets for further improvement of this technology. Based on these results, subsequent leaching tests to evaluate changes in the environmental quality of steel slag have been performed on fresh samples of the two steel slag types and corresponding samples carbonated during $24 \mathrm{~h}$ at $90^{\circ} \mathrm{C}$.

\subsection{Mineralogical characterisation of carbonation products}

As mentioned above, we hypothesised the environmental quality of carbonated steel slag to be related to mineralogical alterations at the steel slag surface, as a result of the reaction with $\mathrm{CO}_{2}$. When determining the alteration phases on the surfaces of reacted grains, calcite was detected by XRD as the only newly formed (crystalline) mineral. The diffraction intensity of the original mineralogy was suppressed by the calcite encrustation. and, conse- quently, no quantitative phase portions were obtained from these measurements.

Reflected light microscopy of the K1 slag grains (Fig. 3) showed that calcite formation occurs mainly on the outside of grains, but that not all surfaces are equally overgrown. The grain at the bottom of Fig. 3 has developed a thick layer of calcite without signs of mineralogical alteration at the exposed surface. The other grain (top) shows some alteration (dark rim) of C2S, but no calcite deposition. These observations imply that calcite deposition was not related to the degree of alteration of the underlying slag mineralogy within a particle but seems to be controlled by external conditions imposed by the fluid covering the grain surfaces during the carbonation experiments. Hence, the carbonation reaction appears to take place in two subsequent steps, rather than by solid-state conversion; calcium is first leached from the Ca-minerals and subsequently reacts with dissolved carbonate to form calcite that precipitates on the surface of the steel slag particles. This sequence has also been observed (Huijgen et al., 2005) to occur during the carbonation of steel slag in an autoclave at high temperature and pressure $\left(T=150{ }^{\circ} \mathrm{C} / p \mathrm{CO}_{2}=20 \mathrm{bar}\right)$.

Results from reflected light microscopy of the carbonated $\mathrm{K} 3$ slag are given in Fig. 4. The carbonated K3 slag shows severe fracturing in contrast to the observations for $\mathrm{K} 1 \mathrm{slag}$. This phenomenon is caused by volume expansion of the reacting free lime, resulting in more extensive development of alteration rims on both C3Srelicts and C2S (Fig. 4). The large C3S grains have a cloudy appearance from lime exsolution while the C2S grains are clear. Dusty material surrounding the grain is largely calcite. The formation of the calcite layer on these mineral phases of the K1 slag (Fig. 3) has been reported to hinder the further leaching and subsequent reaction of $\mathrm{Ca}$ from the coated particles (Huijgen et al., 2005; Lekakh et al., 2008).

The leaching of vanadium from (carbonated) steel slag is known to be important with respect to the environmental quality of this material (Presslinger and Klepp, 2002). Therefore, the 

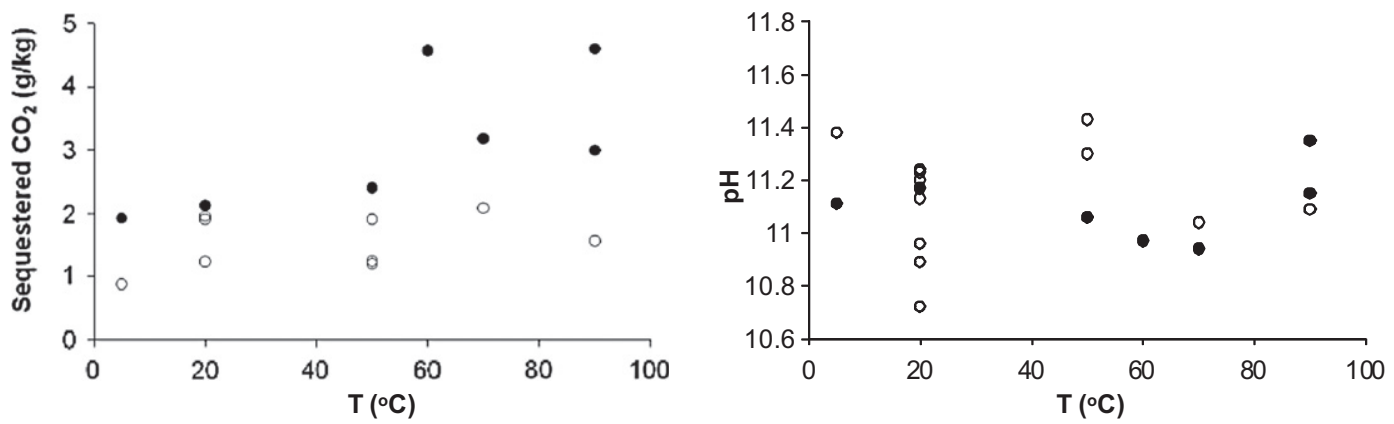

Fig. 2. Sequestered $\mathrm{CO}_{2}$ and resulting $\mathrm{pH}$ (at $L / S=10 \mathrm{~L} / \mathrm{kg}, 48 \mathrm{~h}$ equilibration) in $\mathrm{K} 1$ steel slag particles (2-3.3 mm) as a function of reaction temperature during watersaturated (solid circles) and under-saturated (open circles) conditions at 0.2 bar $p \mathrm{CO}_{2}$ and $24 \mathrm{~h}$ reaction time.

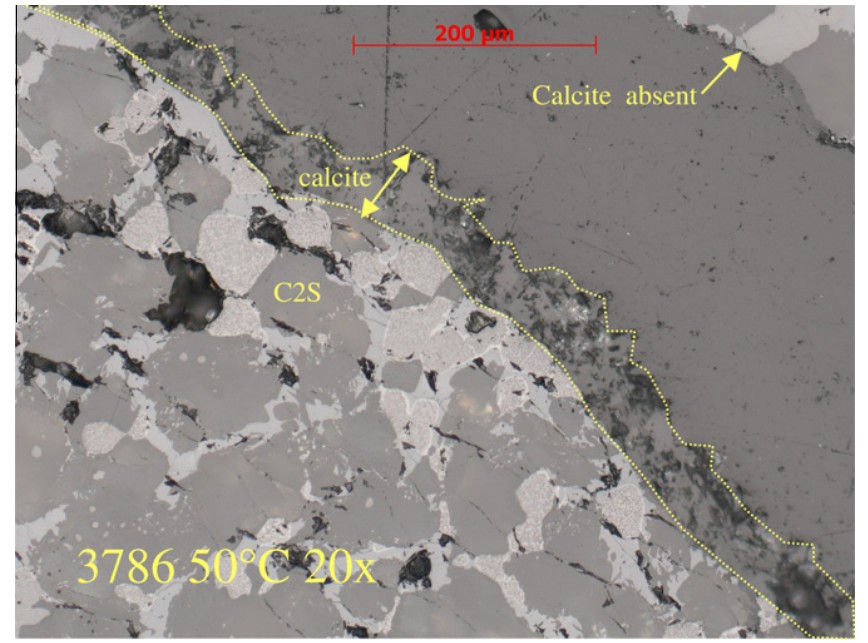

Fig. 3. Two grains of $\mathrm{K} 1$-a from a water-saturated carbonation experiment after exposure for $24 \mathrm{~h}$ to a humid $\mathrm{CO}_{2}-\mathrm{Ar}$ atmosphere at $50{ }^{\circ} \mathrm{C}\left(p \mathrm{CO}_{2}=0.2 \mathrm{bar}\right)$.

mineralogical phases and element distribution patterns of vanadium were determined for carbonated K1-a (Fig. 5) and K3 slag (Fig. 6). The top left image in these Figures represent the backscatter images of the carbonated $\mathrm{Kl}-\mathrm{a}$ and $\mathrm{K} 3$ grains. The arrows with the label "alt." point to various alteration areas (darker grey) of the $\mathrm{C} 2 \mathrm{~S}$ grains. The top right images show the distribution of $\mathrm{V}$, the bottom left images show the distribution of $\mathrm{Ca}$ and the bottom right images represent the distribution of Fe. The alteration rims represent a residue containing phosphate and silica. The element distribution patterns clearly show V-enrichment at the rims of the $\mathrm{C} 2 \mathrm{~S}$-crystal and on the borders of $\mathrm{C} 2 \mathrm{~F}$ phases for both slag qualities. The dark areas in the backscatter image (alteration rims) correspond to the brighter red areas in the V-distribution image.

The MW-phases and the lime phases (for K3 slag) contain no V. The alteration rims on the $\mathrm{C} 3 \mathrm{~S}$ phases in the $\mathrm{K} 3 \mathrm{slag}$ are $\mathrm{V}$-enriched (see top-left corner grain in Fig. 6). The top right facet of the large C2F grain in the centre of Fig. 6 is also clearly altered and enriched in both Fe and V.

Fig. 5 and Fig. 6 show that unaltered C2S and C2F phases at the inside of the slag grains contain the highest $\mathrm{V}$-concentrations in their outer zones. This zoning is related to the primary solidification process of molten slag where cores of phases are solidified at higher temperatures than their outer zones that appear to be enriched in V. Calcite, C3S and MW do not contain V. Therefore, the observed $\mathrm{V}$ enrichment of C3S alteration rims appears to be a secondary process, caused by sorption or precipitation of $\mathrm{V}$ that was previously leached from $\mathrm{C} 2 \mathrm{~S}$ and $\mathrm{C} 2 \mathrm{~F}$ phases. It can also be seen

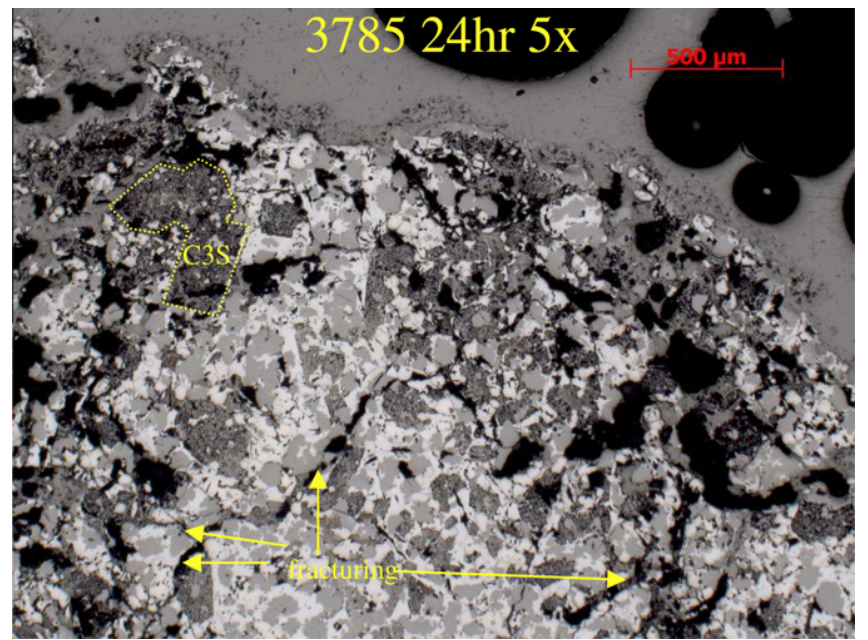

Fig. 4. A heavily fractured grain of $\mathrm{K} 3$ slag after $24 \mathrm{~h}$ exposure to a $\mathrm{CO}_{2}-\mathrm{Ar}$ gas atmosphere at $95{ }^{\circ} \mathrm{C}$ under water-saturated conditions $\left(p \mathrm{CO}_{2}=0.2 \mathrm{bar}\right)$. The indicated C3S phase is exsolved into $\mathrm{C} 2 \mathrm{~S}$ and lime.

that there is Ca-loss from altered C2S (for both slag types), with possibly some additional, secondary, V-enrichment at the mineral surface (e.g., top right edge of the C2S grain shown at the top left corner of Fig. 5).

The mineralogical characterisation clearly shows that the carbonation process results in (incongruent) dissolution of $\mathrm{Ca}$ from C2S (Fig. 5, top left corner of Ca image) and, to a lesser extent, $\mathrm{C} 2 \mathrm{~F}$ and subsequent reaction with dissolved carbonate, followed by calcite precipitation on the surface of the steel slag particles (calcite particles on the alteration layer in Fig. 5). The calciumbearing phases $\mathrm{C} 2 \mathrm{~S}$ and $\mathrm{C} 2 \mathrm{~F}$ are also shown to be the primary $\mathrm{V}$ containing minerals in the steel slag. In the process of their partial dissolution, $\mathrm{V}$ is partly redistributed and enriched in alteration rims, particularly on C3S. The effect of these mineralogical alterations on the leaching properties of steel slag is addressed in the next section.

\subsection{Leaching behaviour of fresh and carbonated steel slag}

Fig. 7 shows the leaching of $\mathrm{Ca}, \mathrm{Si}$ and $\mathrm{V}$ from fresh and carbonated steel slag as a function of pH. The solubility and leaching of Calcium increases strongly and consistently towards low $\mathrm{pH}$ and this pattern is likely to originate from the (partial) dissolution of the alkaline lime and $\mathrm{Ca}$ - (and V) bearing $\mathrm{C} 2 \mathrm{~S}$ and $\mathrm{C} 2 \mathrm{~F}$ phases. Si has previously been observed (Zinngrebe et al., 2004) to be released primarily from $\mathrm{C} 2 \mathrm{~S}$, and simultaneously with $\mathrm{V}$. The 


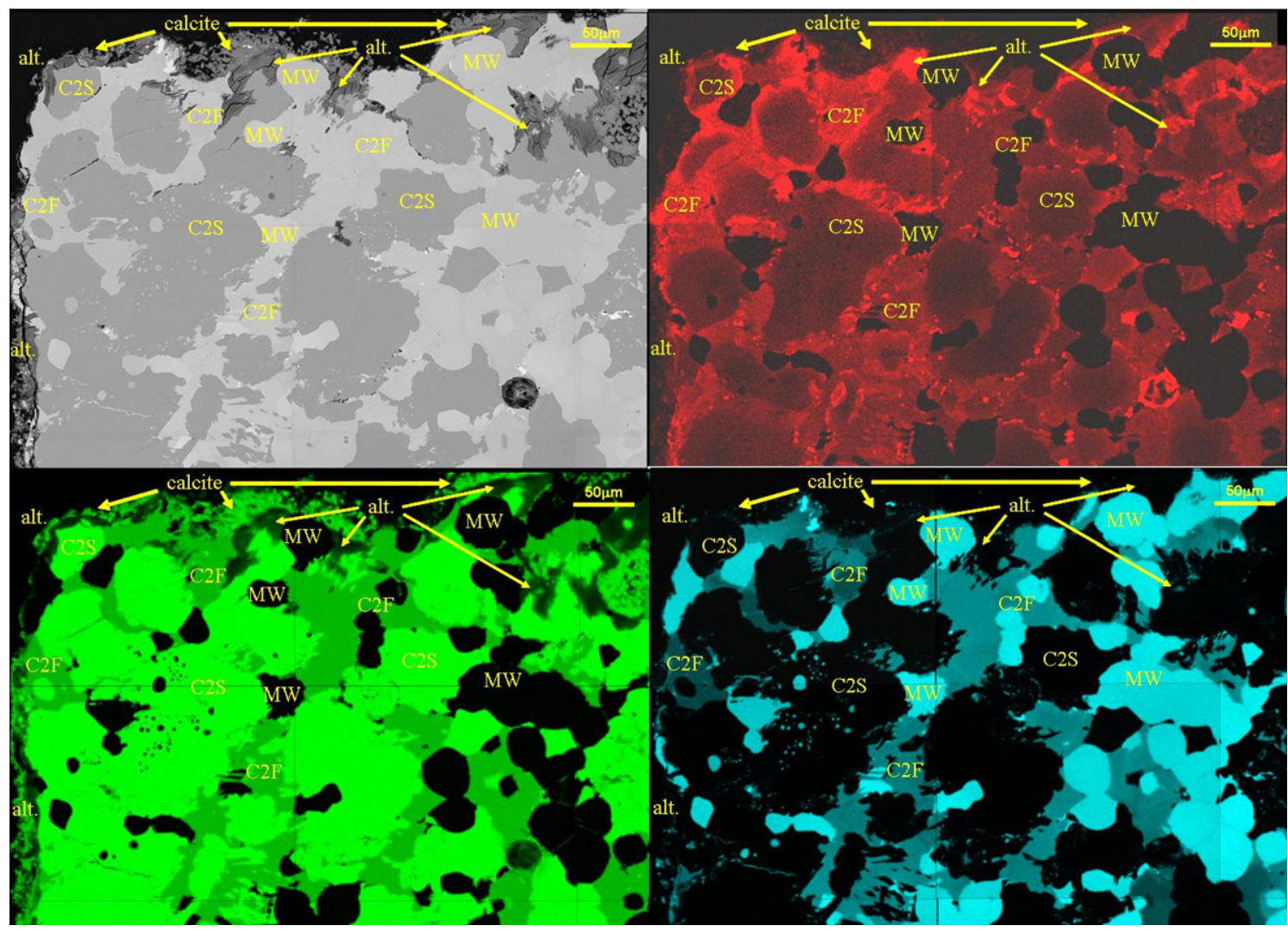

Fig. 5. SEM backscatter image and element distribution of carbonated K1-a $\operatorname{slag}\left(24 \mathrm{~h}, 50^{\circ} \mathrm{C}\right.$, water saturated conditions), top left: SEM Backscatter Image in which grey levels correspond to the three slag phases, magnesio-wuestite (marked MW) and Srebrodolskite (marked C2F) are equally bright; Larniet (C2S) is distinctly darker grey. Alteration (marked alt.) occurs only in C2S grains and is even darker and patchy grey; top right: V-distribution; bottom left; Ca-distribution, bottom right: Fe-distribution.

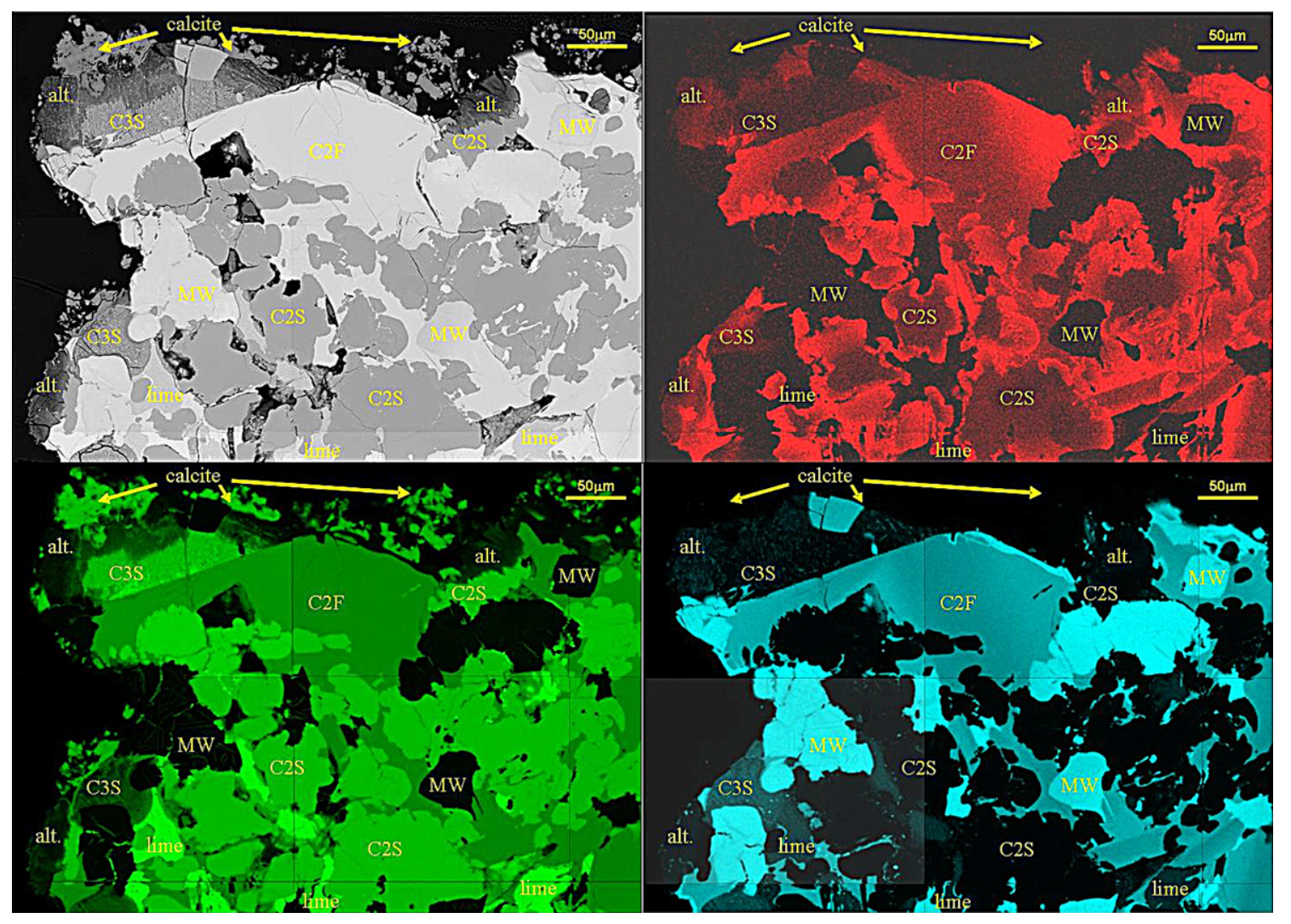

Fig. 6. SEM backscatter image and element distribution of carbonated $\mathrm{K} 3$-slag $\left(24 \mathrm{~h}, 95^{\circ} \mathrm{C}\right.$, water saturated conditions). Top left: SEM Backscatter Image; top right: Vdistribution; bottom left; Ca-distribution, bottom right: Fe-distribution. The indicated C3S phase is exsolved into C2S and lime. Alteration products are marked with "alt". 

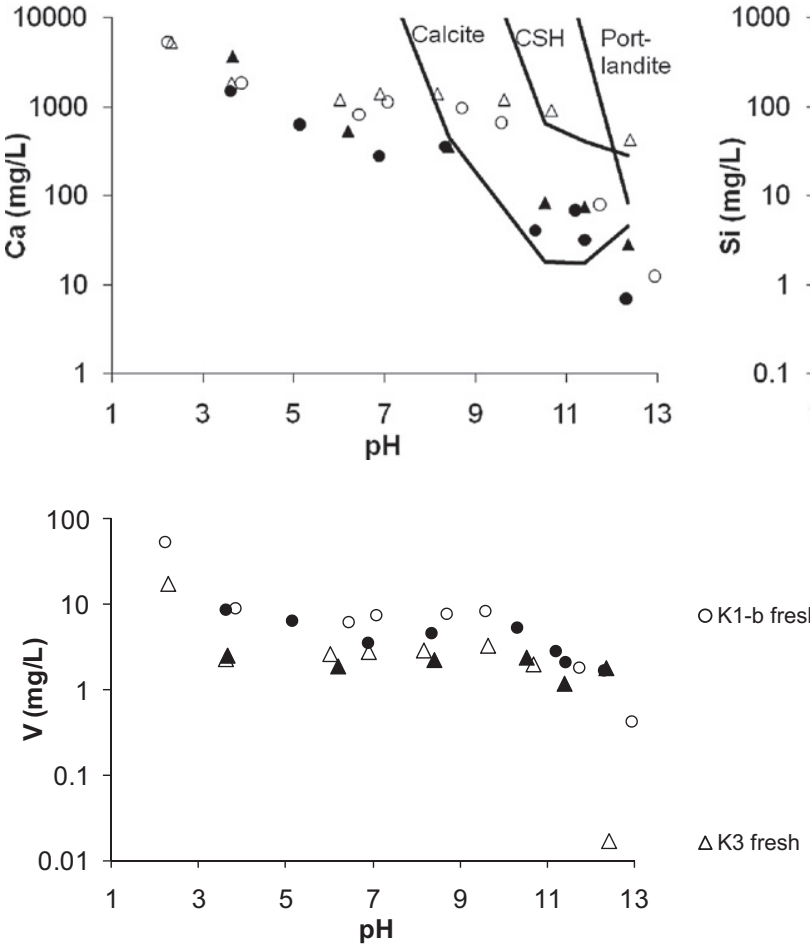

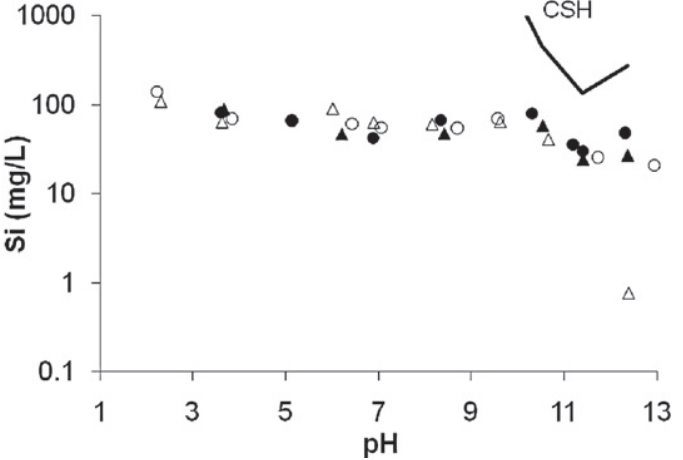

K1-b carbonated saturated

K3 carbonated saturated

Fig. 7. Leaching of $\mathrm{Ca}$, Si and $\mathrm{V}$ from fresh and carbonated $\left(90^{\circ} \mathrm{C}\right.$ for $\left.24 \mathrm{~h}\right)$ steel slag as a function of pH. Lines represent the calculated Ca and Si leaching assuming solubility control by mineral phases. The native $\mathrm{pH}$ of the fresh slag samples was 11.7 (K1) and 12.4 (K3). After carbonation, the native pH of the samples was 11.2 (K1) and 11.4 (K3).

optical microscopic analysis of the carbonated steel slag has shown that $\mathrm{C} 2 \mathrm{~S}$ phases have been altered to a much higher degree than $\mathrm{C} 2 \mathrm{~F}$. Given these findings and the rather similar $\mathrm{V}$ content of these phases (Table 2), leached $\mathrm{V}$ is, therefore, believed to originate largely from the partial dissolution of C2S. Fig. 7 does also show that the leaching of $\mathrm{Ca}$ is substantially reduced after carbonation of both slag types.

The processes behind the observed differences in the pH-dependent leaching of $\mathrm{Ca}$ from the different steel slag samples have been further examined by geochemical modelling. This approach contributes to bridge the mineralogical observations with the leaching data, particularly with regard to the major mineral phases that control the Ca solubility. Potential mineral phases involved in the leaching of Ca were selected based on the mineralogical characterisation (Table 1 ). For the fresh materials, solubility products of portlandite $\left(\mathrm{Ca}(\mathrm{OH})_{2}\right)$ and $\mathrm{CSH}\left(\mathrm{Ca}_{1.1} \mathrm{SiO}_{7} \mathrm{H}_{7.8}\right)$ (Gaucher et al., 2004) were selected as proxies for free lime and C2S, respectively. The mineral $\mathrm{Ca}_{1.1} \mathrm{SiO}_{7} \mathrm{H}_{7.8}$ was chosen based on previous work (Huijgen and Comans, 2006), where it was observed that this mineral phase adequately described the leaching behaviour of $\mathrm{Si}$ in fresh steel slag. Although we note that the selection of this mineral phase, and particularly its stoichiometrical composition remains somewhat subjective, the solubility of $\mathrm{Ca}$ and $\mathrm{Si}$ is reasonably well approximated by $\mathrm{CSH}$ between $\mathrm{pH} 11$ and the native $\mathrm{pH}$ of the fresh K3 slag (=12.4 for K3 slag after $48 \mathrm{~h}$ of water contact). At this native $\mathrm{pH}, \mathrm{Ca}$ is also close to equilibrium with co-existing portlandite (Fig. 7; see also Eq. (1) below).

For the carbonated steel slags, the pH-dependent Ca concentration in equilibrium with calcite was calculated. The lower Ca concentration in the leachates of the carbonated slags ( $\mathrm{pH}$ interval 610) tend towards the values predicted in equilibrium with calcite, which has a significantly lower solubility than the original $\mathrm{Ca}$ phases. The carbonated K3 slag still contains portlandite but this mineral is present inside the grains and protected from leaching by the unaltered minerals, the alteration rims and the calcite layer around the grains (Fig. 6).
The leaching pattern of $\mathrm{V}$ is qualitatively identical to the leaching of Si. This observation suggests that the leaching of $\mathrm{V}$ and $\mathrm{Si}$ is governed by the same mineralogical changes during carbonation. As indicated by the above mineralogical analysis, the observed partial dissolution of the $\mathrm{V}$-bearing $\mathrm{C} 2 \mathrm{~S}$ phase is most probably responsible for these effects. It has been suggested that $\mathrm{V}$ is incorporated as vanadate $\left(\mathrm{VO}_{4}^{3-}\right)$ in the $\mathrm{C} 2 \mathrm{~S}$ phase of fresh steel slag (Presslinger and Klepp, 2002).

The fresh K3 steel slag contains free lime, leading to its native $\mathrm{pH}$ of 12.4. At these alkaline conditions $\mathrm{V}$ is relatively immobile. However, as Fig. 7 shows, the $V$ leaching drastically increases when the $\mathrm{pH}$ is lowered (as a result of acid addition in the pH-stat) to values of about 11 or less. This leaching pattern is consistent with the dissolution of (V-bearing) C2S and subsequent formation of $\mathrm{CSH}$ and portlandite, which can be represented by the general equation:

$\mathrm{C} 2 \mathrm{~S}+m \mathrm{H}_{2} \mathrm{O}=\mathrm{CSH}_{m-1}+\mathrm{Ca}(\mathrm{OH})_{2}$

Eq. (1) shows that the dissolution of $\mathrm{C} 2 \mathrm{~S}$ is limited by the presence of portlandite, particularly in case of a free lime buffer such as in $\mathrm{K} 3$ slag. Hence, the leaching of $\mathrm{V}$ from dissolving $\mathrm{C} 2 \mathrm{~S}$ is strongly reduced when portlandite is present (i.e. at the native $\mathrm{pH}$ of $\mathrm{K} 3$ slag; Fig. 7). Carbonation of K3 slag clearly shows that V leaching also increases as a result of this treatment, due to the transformation of portlandite to calcite and subsequent partial dissolution of $\mathrm{C} 2 \mathrm{~S}$, with more intensive carbonation of the slag leading to higher $\mathrm{V}$ mobility, as will be shown below.

The fresh K1 steel slag shows a relatively high V leaching at high $\mathrm{pH}$, probably as a result of the absent (or very limited) portlandite buffer, allowing greater $\mathrm{C} 2 \mathrm{~S}$ dissolution. When the $\mathrm{pH}$ of this slag is decreased by carbonation and/or by addition of acid in the pH-static leaching test, the $\mathrm{C} 2 \mathrm{~S}$ dissolution and $\mathrm{V}$ leaching increase. These results are consistent with those of Huijgen and Comans (2006), although the severe carbonation at elevated temperature and pressure in that study does result in even higher $\mathrm{V}$ emissions between $\mathrm{pH} 11$ and 13. The effects of carbonation on $\mathrm{pH}$ and the leaching of $\mathrm{V}$ was further tested with the upflow percolation test to verify 

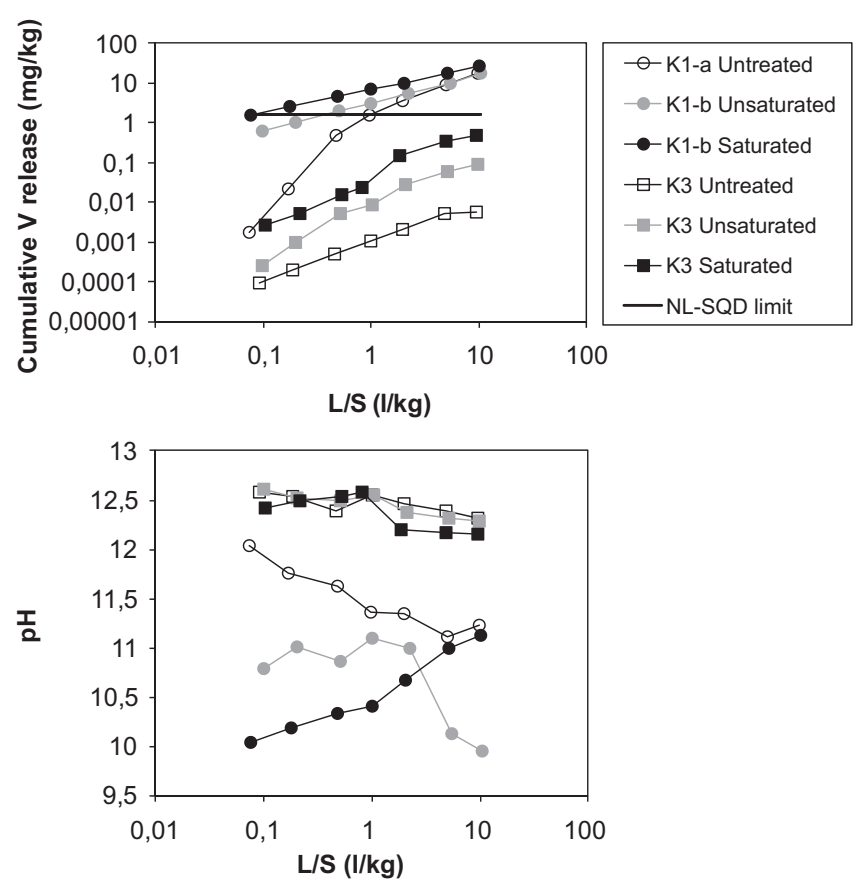

Fig. 8. Cumulative release of $\mathrm{V}$ (top) and leachate $\mathrm{pH}$ (bottom) as a function of liquid/solid $(L / S)$ ratio for untreated and carbonated $\mathrm{K} 1$ and $\mathrm{K} 3 \mathrm{slag}$, under both water-saturated and unsaturated conditions. NL-SQD refers to the limit value for $\mathrm{V}$ leaching as specified in the Dutch Soil Quality Decree.

compliance with limit values specified in the Dutch Soil Quality Decree (SQD; as published in 2008).

Fig. 8 shows the cumulative release of $\mathrm{V}$ and the leachate $\mathrm{pH}$ in the percolation tests with $\mathrm{K} 1$ and $\mathrm{K} 3$ slag, before and after carbonation using water-saturated and -unsaturated conditions. The $\mathrm{pH}$ of the treated slag showed a short-lived improvement, starting at around 10 (K1-b saturated) to 10.8 (K1-b unsaturated) but with a rebound to around 11 for K1-b saturated (original $\mathrm{pH}$ of the K1 slag was 11.7). However, the K1-b slag that was carbonated under unsaturated conditions does not show a $\mathrm{pH}$ rebound effect, for reasons that we were unable to identify. The K3 slag does not show any differences in the $\mathrm{pH}$ between the fresh and carbonated samples. This large difference in the leachate $\mathrm{pH}$ development of $\mathrm{K} 1$ and $\mathrm{K} 3$ slag is in agreement with the presence of a larger amount of free lime in the $\mathrm{K} 3$ steel slag (Table 1), i.e., the $\mathrm{pH}$ determining phase in the fresh slag (Fig. 7). Huijgen et al. (2005) showed that portlandite is the Ca-phase most susceptible to carbonation of the three phases present. The results in Fig. 8 indicate that the surface reactions seem to be effective for neutralisation of the $\mathrm{pH}$, confirming earlier work (Huijgen et al., 2005). We have observed that carbonation only takes place on the surface of the grains in both the $\mathrm{K} 1$ and $\mathrm{K} 3$ slags, as shown in Fig. 3. During the carbonation treatment, portlandite is partly formed from $\mathrm{CaO}$ inside the grains of $\mathrm{K} 3 \mathrm{slag}$. This process results in the formation of cracks due to volume expansion (Fig. 4), resulting in a slow (diffusive) release of alkalinity from unreacted portlandite in the inner grains. This effect was not observed for $\mathrm{K} 1$ slag due to its limited $\mathrm{CaO}$ content.

The carbonation was observed to lead to an increased V-leaching in both the pH-stat test (Fig. 7) and the column test (Fig. 8) for the K3 slag. The leaching of vanadium from the K3 slag remained below the Dutch limit values $(<1 \mathrm{mg} / \mathrm{kg}$ ), although it was found to increase substantially after carbonation. Both the fresh and the carbonated K1 slag were found to exceed the limit values of the Dutch SQD for an open application without isolation measures. Comparing samples carbonated under unsaturated conditions (lower degree of carbonation; see Fig. 1) with those carbonated under water-saturated conditions (higher degree of carbonation), shows that increasing the degree of carbonation is paralleled with further increasing vanadium leaching. This effect is most likely the result of the more extensive dissolution of C2S and subsequent $\mathrm{V}$ release.

Improvement of the $\mathrm{K} 1$ steel slag $\mathrm{pH}$ by carbonation appears incompatible with an acceptable leaching of $\mathrm{V}$ (leaching of $\mathrm{V}$ from untreated material was already higher than limit value). The results in Fig. 8 imply that a further improvement of the pH of K3 slag would be needed to substantially lower this parameter to an acceptable value. However, our findings strongly suggest that the $\mathrm{V}$ leaching in the K3 slag would then also increase beyond the criteria specified in the SQD.

\section{Conclusions}

Accelerated carbonation of steel slag at relatively low $p \mathrm{CO}_{2}$ pressure ( 0.2 bar) and water-saturated and under-saturated conditions was investigated as a potential method to improve the environmental properties of steel slag. In general the reaction was found to proceed fastest at higher temperature $\left(50-90^{\circ} \mathrm{C}\right)$ in the presence of water. Carbonation at these conditions was found to occur predominantly at the surface of the slag grains, the free lime containing slag (K3-slag) being more prone to carbonation (about $15 \mathrm{~g} \mathrm{CO}_{2} / \mathrm{kg}$ ) than the slag with lower free lime content (K1-slag) (about $6 \mathrm{~g} \mathrm{CO}_{2} / \mathrm{kg}$ ). The major changes in the amount of sequestered $\mathrm{CO}_{2}$ and the resulting $\mathrm{pH}$ reduction occurred within $24 \mathrm{~h}$. The formation of cracks was observed after carbonation of the K3 slag, suggesting that free lime in the interior of slag grains had also reacted. The $\mathrm{pH}$ of the $\mathrm{K} 3$ slag was reduced by about 1.5 units, suggesting that the material is substantially improved with respect to its alkalinity. The $\mathrm{K} 1 \mathrm{slag}$ showed a smaller decrease in $\mathrm{pH}$ from about 11.7 to 11.1 within $24 \mathrm{~h}$ reaction time. For both slag types, the $\mathrm{pH}$ values after carbonation seem to stabilise around 11.011.3. The $\mathrm{pH}$ reduction after carbonation was observed to lead to an increased V-leaching. In parallel to the $\mathrm{pH}$ reduction, the K1 slag showed a relatively high V-leaching $(10-100 \mathrm{mg} / \mathrm{kg} \mathrm{slag})$ at levels above the limit values of the Dutch Soil Quality Decree (for untreated and treated slag), while the K3 slag remained within acceptable limits ( $<1 \mathrm{mg} / \mathrm{kg}$ slag) at the relatively high $\mathrm{pH}$ that remained after carbonation. It is concluded that improvement of the steel slag $\mathrm{pH}$ by carbonation is largely incompatible with maintaining an acceptable leaching of $\mathrm{V}$. Combined geochemical modelling of the leaching mechanisms and microscopic/mineralogical analysis of fresh and carbonated slag grains have proven to constitute a consistent and valuable approach to identify the major processes that control the slag $\mathrm{pH}$ and resulting $\mathrm{V}$ leaching. The di-Ca silicate (C2S) phase has been found to contain a substantial level of $V$ and its dissolution has been identified as the major source of the $\mathrm{V}$ leaching. In fresh steel slag, particularly K3 slag, the dissolution of $\mathrm{C} 2 \mathrm{~S}$ and the resulting V-leaching are limited by the presence of portlandite. Carbonation of the slag leads, however, to transformation of portlandite to calcite, the subsequent partial dissolution of C2S and release of V. Given that this V-bearing C2S phase is (partially) dissolved during carbonation, further improvement of an accelerated carbonation technology should focus on stimulation of a secondary binding mechanism for $\mathrm{V}$ in the carbonated slag matrix.

\section{Acknowledgements}

The authors thank Enno Zinngrebe for pointing out the proper phase equilibria considerations. Remco Koper is acknowledged for execution of the carbonation- and leaching experiments. 


\section{References}

Allison, J. D., Brown, D. S., Novo-Gradac, K. J. 1991. MINTEQA2/PRODEFA2, A Geochemical Assessment Model for Environmental Systems: Version 3.11 User's Manual. EPA/600/3-91/021, 1-119.

Baciocchi, R., Costa, G., Polettini, A., Pomi, R., 2009. Influence of particle size on the carbonation of stainless steel slag for $\mathrm{CO}_{2}$ storage. Energy Procedia 1, 48594866.

Bonenfant, D., Kharoune, L., Sauvé, S., Hausler, R., Niquette, P., Mimeault, M. Kharoune, M., 2008. $\mathrm{CO}_{2}$ sequestration potential of steel slags at ambient pressure and temperature. Industrial \& Engineering Chemistry Research 47 $7610-7616$.

CEN/TS 14405, 2005. Characterisation of waste - leaching behaviour tests - Upflow percolation test, CEN.

Dijkstra, J.J., van der Sloot, H.A., Comans, R.N.J., 2002. Process identification and model development of contaminant transport in MSWI bottom ash. Waste Management 22, 531-541.

Gaucher, E.C., Blanc, P., Matray, J.-M., Michau, N., 2004. Modelling diffusion of an alkaline plume in a clay barrier. Applied Geochemistry 19, 1505-1515.

Geiseler, J., 1995. Composition and Structure of Slags. In: Verlag Stahleisen GmbH Düsseldorf.

Huijgen, W. J. J., Comans, R. N. J. 2006. Carbonation of steel slag for CO2 sequestration: leaching of products and reaction mechanisms. Environmental Science \& Technology 40, 2790-2796.
Huijgen, W.J.J., Witkamp, G.J., Comans, R.N.J., 2005. Mineral $\mathrm{CO}_{2}$ sequestration by steel slag carbonation. Environmental Science \& Technology 39, 9676-9682.

Lekakh, S.N., Rawlins, C.H., Robertson, D.G.C., Richards, V.L., Peaslee, K.D., 2008. Kinetics of aqueous leaching and carbonization of steelmaking slag. Metallurgical and Materials Transactions B 39, 125-134.

Meeussen, J.C.L., 2003. ORCHESTRA: an object-oriented framework for implementing chemical equilibrium models. Environmental Science \& Technology 37, 1175-1182.

Meima, J.A., Comans, R.N.J., 1997. Geochemical modelling of weathering reactions in municipal solid waste incinerator bottom ash. Environmental Science \& Technology 31, 1269-1276.

Presslinger, H., Klepp, K.O., 2002. Vanadium in converter slags. Steel Research 73, 522-525.

Shi, C., 2004. Steel slag - its production, processing, characteristics, and cementitious properties. Journal of Materials in Civil Engineering 16, 230-236.

van der Sloot, H. A., Seignette, P., Comans, R. N. J., van Zomeren, A, Dijkstra, J. J. Meeussen, J. C. L., Kosson, D. S., Hjelmar, O., 2003. Evaluation of environmental aspects of alternative materials using an integrated approach assisted by a database/expert system. In: Conference on Advances in Waste Management and Recycling. University of Dundee, Dundee, Scotland, pp. 769-790.

Worldsteel, 2010. Steel statistical yearbook 1-122, 2010. Brussels, Worldsteel Committee on Economic Studies.

Zinngrebe, E., van der Laan, S. R., 2004. Magnitude and causes of trace metal (V, Ba, Cr) leaching from slag in NEN 7343 column tests. IJTC/CRC MCT/CK/R/08397 2004/R, 1-58. 2004. IJmuiden, Corus RD\&T. 